\title{
Rancang Bangun Alat Penetas Telur Ayam Otomatis Dengan Metode PID (Proportional Integral Derivative) Berbasis Energy Hybrid
}

\author{
${ }^{\text {a Syafik, }}{ }^{\mathrm{b}}$ Koko Joni, ${ }^{\mathrm{A}}$ Achmad Fiqhi Ibadillah \\ a,b,c Program Studi Teknik Elektro, Fakultas Teknik, Universitas Trunojoyo Madura \\ Jl. Raya Telang, PO Box 2 Kamal, Bangkalan - Madura \\ E-mail: syafiksetiawan@gmail.com, kokojoni@gmail.com, fiqih.achmad@gmail.com
}

\begin{abstract}
Abstrak
Penetasan telur saat ini tidak lagi dilakukan secara alami lewat pengeraman induk, tetapi menggunakan alat penetas telur. Alat penetas telur merupakan suatu alat yang digunakan untuk menghangatkan suhu pada telur ayam sebagai pengganti pengeraman induk ayam. Alat penetas telur yang ada pada saat ini kebanyakan menggunakan metode pengaturan secara manual yang memerlukan pengamatan terus menerus. Hal tersebut sangat tidak efisien. Maka dari itu pada penelitian dirancang alat penetas telur ayam kampung otomatis dengan metode PID (Proportional Integral Derivative) berbasis Energi Hybrid, system ini bekerja dengan cara merubah suhu ruang alat penetas secara otomatis berdasarkan setpoint yang ditentukan. Sistem pemanasan alat penetas telur ini menggunakan lampu yang dikontrol oleh dimmer lighting control serta terdapat rak penampung telur yang digerakan dengan motor servo agar sesuai dengan teori penetasan telur. Dengan menggunakan Energy Hybrid, maka alat penetas telur ayam tersebut dapat tetap menyalah walaupun listrik padam. Sehingga, waktu proses penetasan mencapai hasil yang maksimal. Set point suhu yang digunakan sebesar $38^{\circ} \mathrm{C}$. Hasil yang diperoleh dari keseluruhan pengujian system penetasan telur otomatis mempunyai tingkat keberhasilan sebesar 54,5\%.
\end{abstract}

Kata kunci: Alat Penetas Telur, Telur Ayam Kampung, Dimmer lighting control, Energy Hybrid, PID.

\section{PENDAHULUAN}

Dalam bidang peternakan khususnya dalam peternakan ayam, masalah yang dihadapi adalah Penetasan telur ayam dalam jumlah banyak dan dalam waktu yang bersamaan. Kemampuan induk ayam dalam mengerami telurnya terbatas, yaitu maksimal 10 butir telur tiap induk ayam. Ini menjadi masalah yang serius karena kebutuhan daging dan telur ayam di pasar yang sangat banyak.

Maka untuk menggantikan induk ayam dalam menetaskan telurnya, dibuatlah mesin penetas telur ayam. Mesin penetas telur yang beredar di pasaran saat ini masih manual, terutama pada pemutar rak telur. Untuk kontrol suhunya menggunakan thermostat atau lampu biasa, sehingga hanya menggunakan kontrol on - off.

Untuk melengkapi kekurangan kekurangan pada mesin tetas yang ada di pasaran maka dibuatlah mesin penetas telur ayam berbasis mikrokontroler dengan kontrol PID. Kontrol PID ini digunakan untuk mengontrol suhunya agar sesuai setpoint, sehingga diharapkan tidak terjadi fluktuasi suhu dalam mesin tetas. Alat yang akan dirancang nantinya akan digunakan untuk kontrol temperatur suatu ruangan (mesin penetas telur) secara otomatis dengan menggunakan modul sensor DHT22.

\section{BAHASA DAN METODE}

\section{Blok Disgram Sistem}

Pada Perancangan tugas akhir ini terdapat beberapa tahapan dan alur sistem agar perencanaan sesuai dengan apa yang diharapkan. Berikut adalah rancangan sistem dalam bentuk blok diagram.

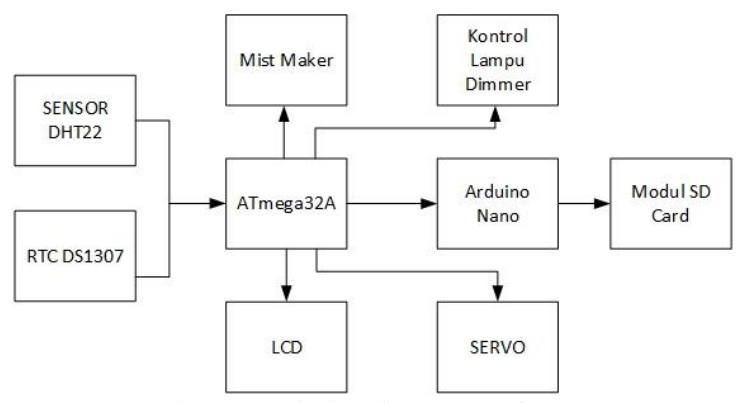

Gambar 1. Blok Diagram Sistem 
Dari gambar 1.1 blok diagram diatas dapat dijelaskan bahwa di bagian input awal blok diagram terdapat sensor suhu dan kelembaban (DHT 22) serta RTC DS1307. Dari sensor DHT22 dan RTC kemudian akan mengirimkan data berupa suhu, kelembaban, hari dan tanggal ke ATmega32A sebagai kontroler utama. Dari ATmega32A kemudian perintah terakhir akan di eksekusi oleh lampu kontrol dimmer dan motor DC servo besar untuk rak telur, agar suhu tetap berada pada set point yang diinginkan. Mist maker disini berfungsi untuk mengatur penurunan nilai kelembaban ruangan. Kemudian semua keadaan tersebut ditampilkan ke LCD. Selain ke LCD data juga dikirimkan ke Arduino nano dan disimpan di SDcard.

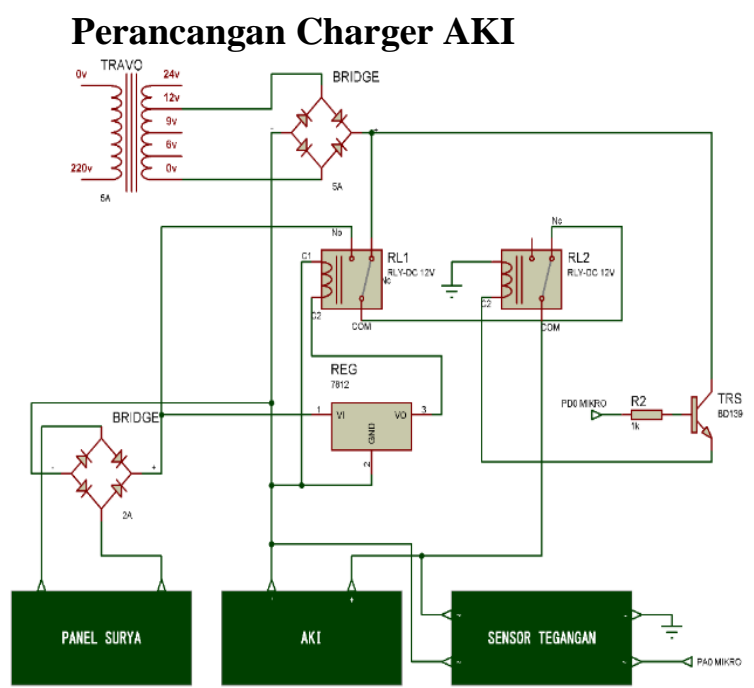

Gambar 2. Perancangan Charger AKI

Dari rangkaian gambar 1.2 diatas dapat dijelasakan bahwa jika tegangan pada panel surya di atas $12 \mathrm{v}$ DC maka di stabilkan oleh regulator 7812 sehingga coil pada relay 1 menerima supply $12 \mathrm{v}$ DC maka relay 1 berada pada kondisi normaly open sehingga aki di charge oleh panel surya. Ketika tegangan pada panel surya dibawah $12 \mathrm{v}$ DC maka coil pada relay 1 tidak menerima supply sehingga relay 1 berada pada kondisi normaly close sehingga aki di charge oleh travo $12 \mathrm{v}$ DC. Sensor tegangan disini untuk mengetahui tegangan pada aki yang dikontrol oleh mikro pada port A0 dan relay 2 sebagai charge atau discharge yang dikontrol oleh mikro pada port D0. Dan panel surya digunakan sebagai supply cadangan ketika listrik PLN mati.

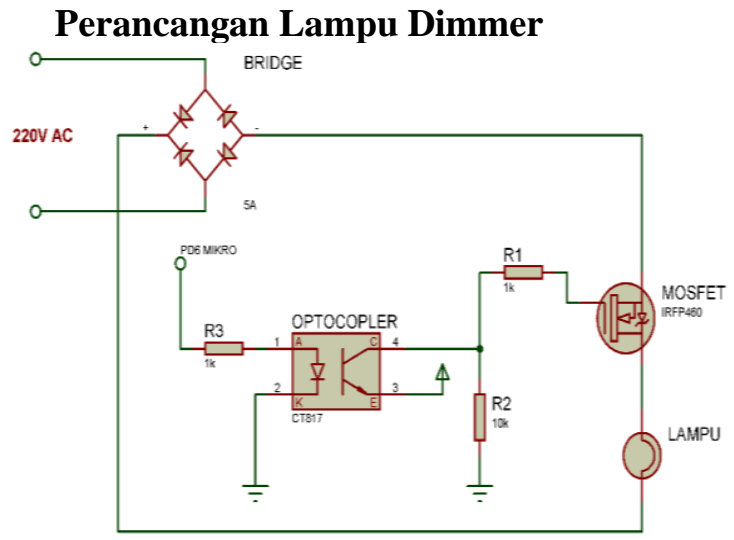

Gambar 3. Perancangan Lampu Dimmer

Dari rangkaian diatas dapat dijelasakan bahwa ketika mikro mengirimkan sinyal input 1 maka akan masuk ke anoda sehingga led menyala dan tegangan positif dari emitor terhubung ke collector. Agar tidak terjadi konselting maka diberi resistor sebesar 20k, sebelum menuju ke mosfet diberi resistor $1 \mathrm{k}$ agar timbul arus pada mosfet tersebut sehingga mosfet dapat aktif dan lampu dapat menyala.

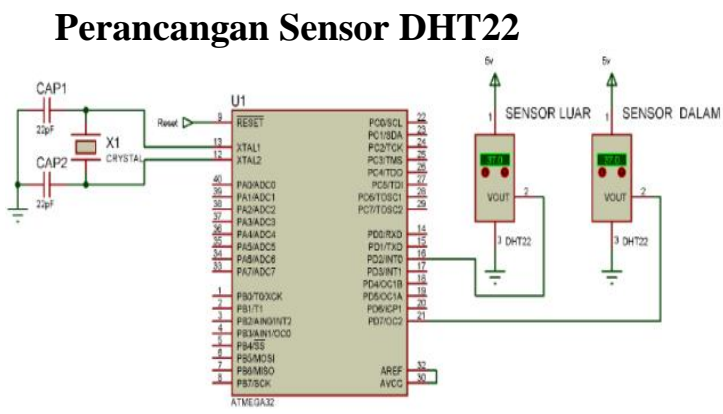

Gambar 4. Perancangan Sensor DHT22

Dari rangkaian gambar 1.4 diatas dapat dijelasakan bahwa DHT-22 adalah chip tunggal kelembaban relatif dan multi sensor suhu yang terdiri dari modul yang dikalibrasi keluaran digital. Pada pengukuran suhu data yang dihasilkan 14 bit, sedangkan untuk kelembaban data yang dihasilkan 12 bit. Keluaran dari DHT-22 adalah digital sehingga untuk mengaksesnya diperlukan pemrograman dan tidak diperlukan pengkondisi sinyal atau ADC. Sensor DHT22 memiliki 3 pin yaitu vcc, data dan ground. Sensor DHT22 memiliki range pengukuran yaitu 0 sampai $100 \%$ untuk kelembaban dan -40 sampai $125^{\circ} \mathrm{C}$ untuk suhu. 


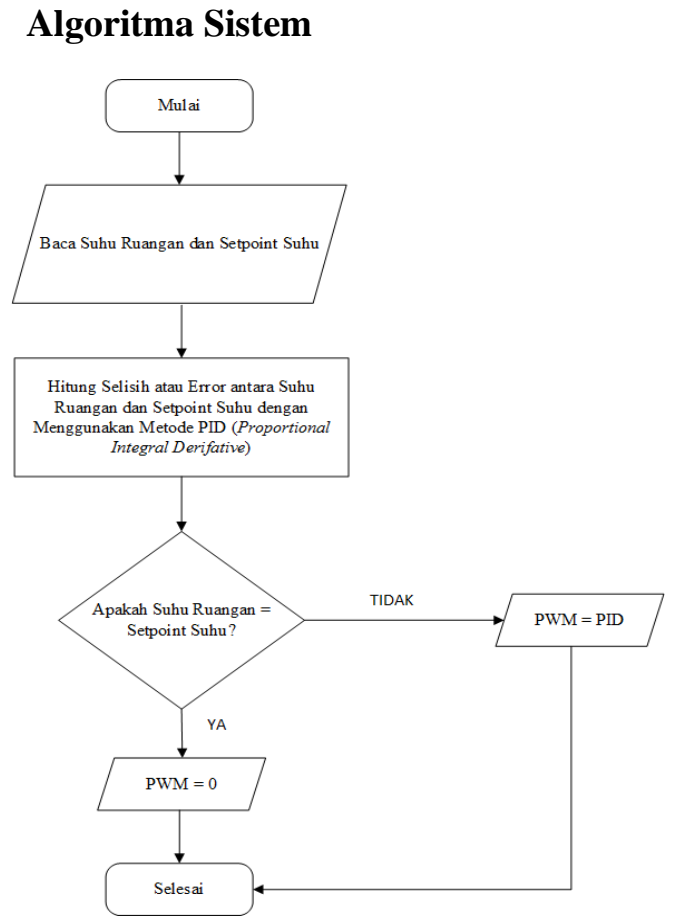

Gambar 5. Algoritma Sistem

Dari flowchart di atas dapat dijelaskan bahwa sistem dimulai dari pembacaan suhu ruangan dan setpoint suhu lalu dihitung errornya dengan menggunakan metode PID. Jika suhu ruangan sama dengan setpoint suhu maka nilai PWM sama dengan 0 maka apa bila suhu ruangan bernilai tidak sama dengan setpoint suhu maka nilai PWM sama dengan hasil perhitungan PID. Nilai PWM inilah yang digunakan untuk mengatur lampu dimmer agar suhu ruangan tetap stabil.

\section{HASIL DAN PEMBAHASAN}

\section{Pengujian Konstanta PID}

Untuk menentukan konstanta PID pada Alat penetas telur dilakukan dengan cara memberikan nilai konstanta proportional terlebih dahulu yang dinaikkan secara bertahap hingga mengalami osilasi terus menerus secara teratur.

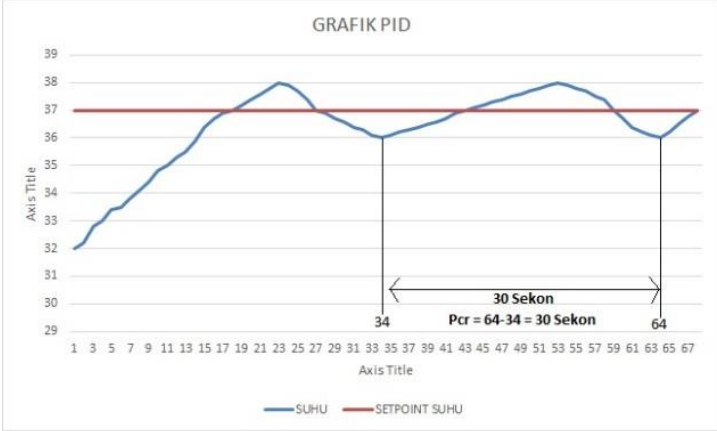

Gambar 6. Pengujian konstanta PID
Dalam percobaan ini plant mengalami osilasi ketika $\mathrm{Kp}=50$. Sehingga $\mathrm{Kcr}=50$. Lalu masukkan pada rumus kontroler PID. Sehingga konstanta PID nya ialah sebagai berikut.

$$
\begin{aligned}
& \mathrm{K}_{\mathrm{p}}=0,6 \times \mathrm{K}_{\mathrm{cr}}=0,6 \times 50=30 \\
& \mathrm{~K}_{\mathrm{i}}=0,5 \times \mathrm{P}_{\mathrm{cr}}=0,5 \times 30=15 \\
& \mathrm{~K}_{\mathrm{d}}=0,125 \times \mathrm{Pcr}=3,75 \cong 4
\end{aligned}
$$

\section{Pengujian System Hybrid}

Sistem hybrid merupakan gabungan dari 2 sistem suply yang berbeda. Dalam pembuatan alat penetas telur ini penulis menggunakan 2 sumber supply antara listrik PLN dengan sumber listrik Batrai yang di supply dari tenaga Surya. Pengujian dilakukan untuk mengetahui apakah system hybrid pada penelitian ini berfungsi dengan baik atau tidak. Pengujian dilakukan dengan mengaktifkan dan menonaktiofkan supply PLN. Berikut adalah gambar pengujian system Hybrid.

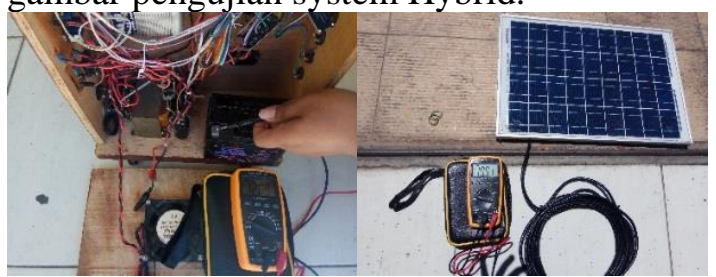

Gambar 7. Pengujian System Hybrid

Dari hasil pengujian didapatkan bahwa tegangan yang dihasilkan Panel surya ketika keadaan panas total adalah sebesar 21 Volt dan baterai dapat terisi hingga 12 volt. Selain proses pengisian pengujian system switching antara PLN dan baterai juga dapat bekerja dengan baik karena dengan adanya rangkain switching relay.

\section{Pengujian 1 Penetasan 8 Butir Telur Ayam Arab}

Percobaan pertama dilakukan dengan meletakan 8 butir telur pada alat penetas telur. Percobaan dilakukan selama 21 hari. Selama percobaan telur telah mengalami beberapa fase diantaranya fase kritis pertama, fase proses dan fase kritis kedua. Diaman di setiap fase telur akan diperlakukan berbeda agar mendapatkan hasil yang maksimal. Pada fase kritis pertama (hari ke-1 - ke 3) rak akan dikondisikan pada posisi datar oleh sistem. Kemudian pada fase proses terhitung dari hari ke-4 sampai hari ke-18 rak akan bergerak miring depan belakang $45^{\circ}$ sebanyak 8 kali dalam satu hari. Dan ketika pada fase kritis kedua (hari ke-19 sampai 21) rak telur akan 
diposisikan lurus kembali. Hingga menunggu telur tersebut menetas. Dari hasil pengujian telur 8 butir telur yang berhasil menetas berjumlah 2 butir. Berikut adalah hasil dokumentasi proses pengujian telur.

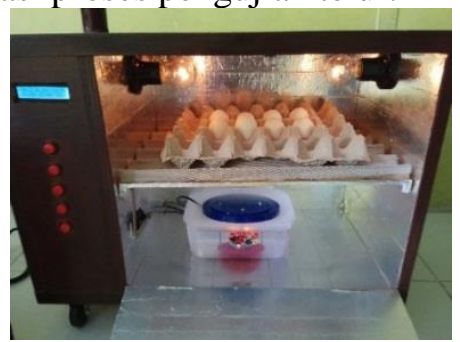

Gambar 8. Pengujian Penetasan 8 Butir Telur Ayam Arab

Dalam pengujian pertama ini. Terbagi menjadi dua hasil pengujian yang berbeda yaitu pengujian pertama (hari ke-13 - hari ke18) suhu dan kelembaban saja. Pengujian kedua (hari ke-18 - hari ke-23) terdapat tambahan kelembaban luar dan dalam serta suhu dalam dan luar. Perbedaan pengujian tersebut dikarenakan pengujian pertama penulis hanya mencoba dua pembacaan sensor sedangkan ketika hari ke 18 terdapat tambahan sensor kelembaban dan suhu luar. Berikut adalah grafik hasil pengujian pertama (hari ke18 - hari ke-23).

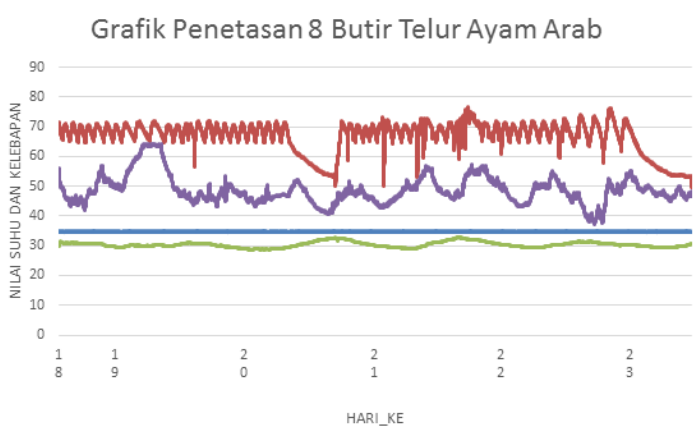

Gambar 9. Grafik Pengujian Penetasan 8 Butir Telur Ayam Arab

Dari grafik di atas dapat dijelaskan bahwa hasil pembacaan sensor suhu dalam menunjukan angka yang stabil di angka $37^{\circ} \mathrm{C}$. Sedangkan pembacaan suhu luar menunjukan data yang kurang stabil. Untuk data kelembaban dalam menunjukan data yang kurang stabil sama halnya dengan kelembaban luar data yang dihasilkan juga kurang stabil.

\section{Pengujian 2 Penetasan 7 Butir Telur Ayam Arab dan 4 Butir Telur Ayam Bangkok}

Percobaan ke-2 dilakukan dengan meletakan 7 butir telur ayam arab dan 4 butir ayam bangkok pada alat penetas telur.
Percobaan dilakukan selama 21 hari. Selama percobaan telur telah mengalami beberapa fase diantaranya fase kritis pertama, fase proses dan fase kritis kedua. Diaman di setiap fase telur akan diperlakukan berbeda agar mendapatkan hasil yang maksimal. Pada fase kritis pertama dan fase proses (hari ke-1 - ke18) rak akan dikondisikan bergerak miring depan belakang $45^{\circ}$ sebanyak 8 kali dalam satu hari oleh sistem. Dan ketika pada fase kritis kedua (hari ke-19 sampai 21) rak telur diposisikan lurus kembali. Hingga menunggu telur tersebut menetas. Dari hasil pengujian telur 7 butir telur ayam arab dan 4 butir ayam bangkok yang berhasil menetas berjumlah 5 butir, terdiri dari 4 butir ayam bangkok dan 1 butir ayam arab.

Dalam pengujian ini. Hasil pengujian yang diambil yaitu pengujian (hari pertama - hari ke-21) suhu luar dan dalam serta kelembaban dalam dan luar. Berikut adalah grafik sensor hasil pengujian 2 (hari pertama - hari ke-21).

Grafik Penetasan 7 Butir Telur Ayam Arab dan 4 Butir Telur Ayam Bangkok

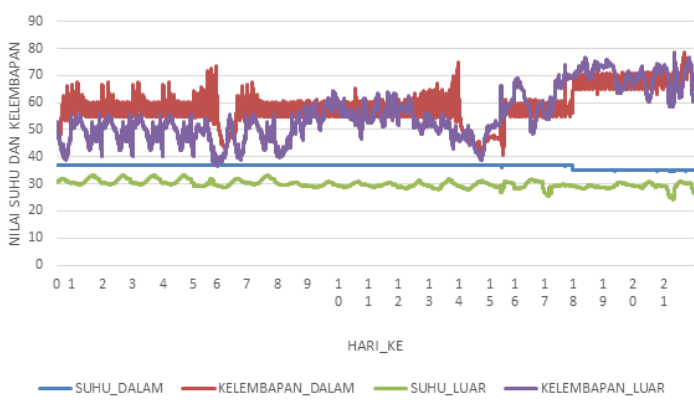

Gambar 10. Grafik Pengujian Penetasan 7 Butir Telur Ayam Arab dan 4 Butir Telur Ayam Bangkok

Dari grafik di atas dapat dijelaskan bahwa hasil dari hari pertama sampai dengan hari ke4 pembacaan sensor suhu dalam menunjukan angka yang stabil di angka $37^{\circ} \mathrm{C}$. Sedangkan pembacaan suhu luar menunjukan data yang kurang stabil. Untuk data kelembaban dalam menunjukan data yang kurang stabil sama halnya dengan kelembaban luar data yang dihasilkan juga kurang stabil.

\section{Pengujian 3 Penetasan 24 Butir Telur Ayam Kampung}

Percobaan ke-3 dilakukan dengan meletakan 24 butir telur ayam kampung pada alat penetas telur. Percobaan dilakukan selama 21 hari. Selama percobaan telur telah mengalami beberapa fase diantaranya fase kritis pertama, fase proses dan fase kritis kedua. Diaman di setiap fase telur akan 
diperlakukan berbeda agar mendapatkan hasil yang maksimal. Pada fase kritis pertama dan fase proses (hari ke-1 - ke-18) rak akan dikondisikan bergerak miring depan belakang $45^{\circ}$ sebanyak 8 kali dalam satu hari oleh sistem. Dan ketika pada fase kritis kedua (hari ke-19 sampai 21) rak telur diposisikan lurus kembali. Hingga menunggu telur tersebut menetas. Dari hasil pengujian telur 24 butir telur ayam kampung dan 14 butir ayam arab yang berhasil menetas berjumlah 16 butir, terdiri dari 7 butir ayam kampung dan 9 butir ayam arab.

Dalam pengujian ini. Hasil pengujian yang diambil yaitu pengujian (hari pertama - hari ke-21) suhu luar dan dalam serta kelembaban dalam dan luar. Berikut adalah grafik sensor hasil pengujian 3 (hari pertama - hari ke-21).

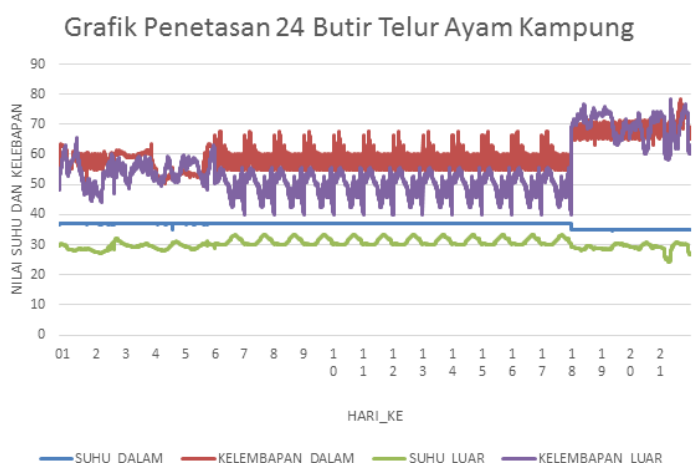

Gambar 11. Grafik Pengujian Penetasan 24 Butir Telur Ayam Kampung

Dari grafik di atas dapat dijelaskan bahwa hasil dari hari pertama sampai dengan hari ke21 pembacaan sensor suhu dalam menunjukan angka yang stabil di angka $37^{\circ} \mathrm{C}$. Sedangkan pembacaan suhu luar menunjukan data yang kurang stabil. Untuk data kelembaban dalam menunjukan data yang kurang stabil sama halnya dengan kelembaban luar data yang dihasilkan juga kurang stabil.

\section{Pengujian 4 Penetasan 21 Butir Telur Ayam Arab}

Percobaan ke-4 dilakukan dengan meletakan 21 butir telur ayam arab pada alat penetas telur. Percobaan dilakukan selama 21 hari. Selama percobaan telur telah mengalami beberapa fase diantaranya fase kritis pertama, fase proses dan fase kritis kedua. Diaman di setiap fase telur akan diperlakukan berbeda agar mendapatkan hasil yang maksimal. Pada fase kritis pertama dan fase proses (hari ke-1 - ke-18) rak akan dikondisikan bergerak miring depan belakang $45^{\circ}$ sebanyak 8 kali dalam satu hari oleh sistem. Dan ketika pada fase kritis kedua (hari ke-19 sampai 21) rak telur diposisikan lurus kembali. Hingga menunggu telur tersebut menetas. Dari hasil pengujian telur 21 butir telur ayam arab yang berhasil menetas berjumlah 17 butir dan 4 gagal.

Dalam pengujian ini. Hasil pengujian yang diambil yaitu pengujian (hari pertama - hari ke-21) suhu luar dan dalam serta kelembaban dalam dan luar. Berikut adalah grafik sensor hasil pengujian 4 (hari pertama - hari ke-21).

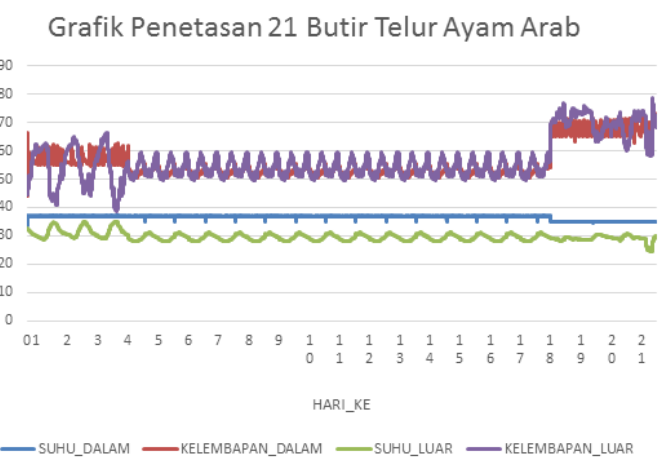

Gambar 12. Grafik Pengujian Penetasan 21 Butir Telur Ayam Arab

Dari grafik di atas dapat dijelaskan bahwa hasil dari hari pertama sampai dengan hari ke21 pembacaan sensor suhu dalam menunjukan angka yang stabil di angka $37^{\circ} \mathrm{C}$. Sedangkan pembacaan suhu luar menunjukan data yang kurang stabil. Untuk data kelembaban dalam menunjukan data yang kurang stabil sama halnya dengan kelembaban luar data yang dihasilkan juga kurang stabil.

\section{KESIMPULAN}

Berdasarkan penelitian hasil perancangan, implementasi dan hasil pengujian hasil alat dan sistem yang telah dibuat dapat disimpulkan bahwa:

1. Dari hasil penelitian ini dapat menciptakan alat penetas telur Otomatis berbasis metode PID (Proportional Integral Derivative).

2. Penerapan system hybrid dapat bekerja dengan baik ketika salah satu dari sumber supply alat mati secara tiba- tiba.

3. Percobaan pertama dari 8 telur menetas 2 butir, percobaan ke dua dari 11 telur menetas 5 butir dan percobaan terakhir dari 24 telur menetas 16 butir. Hasil dari 3 kali percobaan tersebut dapat disimpulkan bahwa penetasan telur menunjukan nilai keberhasilan yang selalu meningkat.

4. Dari beberapa percobaan dapat disimpulkan bahwa percobaan pertama dari 8 butir telur 
ayam arab yang menetas 2 butir, sehingga mempunyai presentase keberhasilan sebesar 25\%, percobaan kedua dari 11 butir telur ayam arab yang menetas 5 butir, sehingga mempunyai presentase keberhasilan sebesar 45,4\%, percobaan ke3 dari 24 butir telur ayam kampung yang menetas 16 butir, sehingga mempunyai presentase keberhasilan sebesar $66,6 \%$ dan percobaan ke-4 dari 21 butir telur ayam arab yg menetas 17 butir, sehingga mencapai nilai keberhasilan hingga $81 \%$. Dari pengujian tersebut dapat disimpulkan bahwa total rata-rata presentases keberhasilan alat penetas telur otomatis berbasis metode PID adalah sebesar 54,5 $\%$.

5. Faktor - faktor yang menyebabkan kegagalan dalam proses penetasan telur diantaranya, Bibit dari telur tidak menentu dan kesalahan pola penetasan yang terkadang terganggu ketika pengambilan data.

\section{DAFTAR PUSTAKA}

[1] Suprapto, A. Tjahjono dan E. Sunarno, "RANCANG BANGUN MESIN PENETAS TELUR AYAM," Teknika, p. 24, 2015.

[2] A. D. Saputra, ALAT PENETAS TELUR BURUNG

WALET OTOMATISDENGAN KONTROL PROPORSIONAL, Solo: Universitas Sebelas maret, 2015.

[3] M. Irfan, "PERANCANGAN SISTEM PENGERAM TELUR AYAM OTOMATIS," Jurnal Teknik Komputer, pp. 148-158, 2014.

[4] I. Nurhadi dan E. Puspita, "RANCANG BANGUN MESIN PENETAS TELUR OTOMATIS BERBASIS MIKROKONTROLER ATMEGA8 MENGGUNAKAN SENSOR SHT 11," Politeknik Elektronika Negeri Surabaya, Surabaya, 2015.

[5] P. Hartanto, "KONTROL SUHU UNTUK MENJAGA SUHU ADONAN PERMEN dan VALVE UNTUK MENGELUARKAN PERMEN SEBESAR 2,5 GRAM," Politeknik Elektronika negeri Surabaya (PENS), vol. II, no. 7, pp. 23-30, 2015.
[6] T. B. Pratomo, A. Dharmawan, A. Syoufian dan T. W. Supardi, "Purwarupa Sistem Kendali Suhu dengan Pengendali PID pada Sistem Pemanas dalam Proses Refluks/Distilasi," IJEIS, vol. III, no. 11, pp. 23-34, 2013.

[7] wikipedia, "Wikipedia Ensiklopedia Bebas," Wikipedia, 23 Januari 2017. [Online]. Available: https://id.wikipedia.org/wiki/Ayam_arab. [Diakses 18 Agustus 2017].

[8] Agrowindo, Buku Panduan Praktis Mesin Penetas Telur Otomatis Sistem Rak Putar, Malang: Agrowindo, 2016.

[9] K. Joni, M. Ulum dan Z. Abidin, "Robot Line Follower Berbasis Kendali ProportionalIntegral-Derivative (PID) Untuk Lintasan Dengan Sudut Ekstrim," INFOTEL, vol. VIII, no. 2, p. 140, 2016.

[10] I. C. Gunadin, "Analisis Penerapan PID Controller Pada AVR (Automatic Voltage Regulator)," Media Elektrik, vol. 3, no. 2, pp. 4-5, 2008. 